\title{
doispontos:
}

\section{Revisando Foucault:}

\section{homo politicus e homo oeconomicus}

Terceiro capítulo do livro Undoing the Demos: Neoliberalism's Stealth Revolution, de Wendy Brown (Nova Iorque: Zone Books / MIT Press, 2015).

Tradução de Danielle Guizzo Archela, Gustavo Hessmann Dalaqua e Sibele Paulino. ${ }^{1}$ gustavodalaqua@yahoo.com.br

Resumo: Tradução do terceiro capítulo de Undoing the Demos, livro no qual Wendy Brown procura compreender como a emergência do homo oeconomincus subjugou outras figurações e interpelações do humano. Brown primeiro apresenta uma leitura crítica da teorização do homo oeconomicus que Foucault formulou em suas aulas sobre o neoliberalismo no Collège de France. A autora censura o filósofo francês por não ter atentado suficientemente para o homo politicus, lócus da soberania popular que consegue resistir a hegemonia do homo oeconomicus. Em seguida, reflete sobre a morfologia e posicionamento variáveis do homo oeconomicus e do homo politicus nos trabalhos de Adam Smith, Locke, Rousseau, Hegel, Marx, Bentham e J. S. Mill. Por último, analisa o gênero do homo oeconomicus contemporâneo e discute a disseminação do homo oeconomicus por meio da ordem de uma razão normativa e de uma racionalidade governante construída sobre essa ordem.

Palavras-Chave: neoliberalismo; homo oeconomicus; homo politicus; Foucault; gênero; soberania popular.

\section{Revising Foucault: homo politicus and homo oeconomicus}

Abstract: Translation of the third chapter of Undoing the Demos, a book where Wendy Brown seeks to understand how the emergence of homo oeconomicus has vanquished other figurations and interpellations of the human. Brown first critically engages with Foucault's theorization of homo oeconomicus in his Collège de France lectures on neoliberalism. She reproaches the French philosopher for not having paid enough attention to homo politicus, the locus of popular sovereignty that can resist the hegemony of homo oeconomicus. Next, she reflects upon the changing morphology and positioning of homo oeconomicus and homo politicus in the works of Adam Smith, Locke, Rousseau, Hegel, Marx, Bentham and J. S. Mill. Then, she analyzes the gender of contemporary homo oeconomicus and discusses the dissemination of homo oeconomicus via an order of normative reason and a governing rationality built on that order.

Key-words: neoliberalism; homo oeconomicus; homo politicus; Foucault; gender; popular sovereignty.

Hoje é um lugar-comum dizer que os valores do mercado suplantam todos os outros e que coisas vulneráveis, preciosas ou sagradas, incluso a própria democracia, têm sido sujeitadas aos mercados de forma crescente e inapropriada. Esse lamento, junto de análises de suas fontes e trajetória, ecoa rotineiramente no discurso popular e acadêmico (SANDEL, 2012a e 2012b). ${ }^{2}$ Neste capítulo, ofereço uma exploração teórica de uma faceta específica desse fenômeno: como o triunfo neoliberal do homo oeconomicus enquanto figura 
abrangente do humano está minando práticas democráticas e um imaginário democrático ao subjugar o sujeito que se governa por meio da autonomia moral e que governa com outros por meio da soberania popular. $\mathrm{O}$ argumento é que valores econômicos não esgotaram o político ou tornaram-se predominantes sobre ele. Mais precisamente, a iteração neoliberal do homo oeconomicus está extinguindo o agente, a língua e os domínios nos quais a democracia - qualquer variedade dela - se materializa.

O homo oeconomicus há muito tem sido tema de análise crítica. Existe uma vasta produção acadêmica sobre sua origem (HIRSCHMAN, 1977; LAVAL, 2007; MAUSS, 1990; TABAS, 2009), morfologia variável (BOWLES et al., 1992; DIXON et al., 2012; LAVAL, 2007) e ontologização e universalização problemáticas (SAHLINS, 1972; POLANYI, 2001; MAUSS, 1990). ${ }^{3}$ Há várias críticas da Weltanschauung que se anunciam por sua proeminência crescente na modernidade, incluso a preocupação com os caminhos com os quais reduz o humano, desencanta o mundo e impede valores alternativos (WEBER, 1948; THUILLIER, 1995; KLAMER, 2001; SAHLINS, 2013; LAVAL, 2007). ${ }^{4}$ Esses diversos estudos e análises contribuem para o meu argumento, mas nenhum o apreende. Embora seja importante entender quem e o que é esse ser como e quando passa a existir na história e no pensamento ocidentais - e as diferenças em suas iterações históricas, meu objetivo é compreender como ele finalmente subjuga outras figurações e interpelações do humano e com quais consequências. Como o homo oeconomicus triunfa sobre essas outras figuras para tornar-se normativo em cada esfera? E quais são exatamente sua forma, comportamento e conteúdos quando isso ocorre? Quem é o homo oeconomicus no momento do seu triunfo?

Este capítulo persegue tais questões, primeiro, ao tratar brevemente da teorização de Foucault do homo oeconomicus em suas aulas sobre o neoliberalismo no Collège de France; segundo, ao refletir sobre a morfologia e posicionamento variáveis do homo oeconomicus e do homo politicus na história do pensamento político ocidental; depois por breves reflexões sobre o gênero do homo oeconomicus contemporâneo e, finalmente, por uma discussão sobre sua disseminação via ordem da razão normativa e da racionalidade governante construída sobre essa ordem.

\section{O homo oeconomicus de Foucault}

Nas aulas do Collège de France, entre 1978 e 1979, Foucault descreve uma mudança no homo oeconomicus da economia clássica e do neoliberalismo, na qual uma imagem do homem como um ser de necessidades satisfeitas através da troca dá lugar a outra de empreendedor de si mesmo (FOUCAULT, 2004). "A feição característica do conceito clássico de homo oeconomicus", diz Foucault, "é o parceiro de troca e a teoria da utilidade baseada em uma problemática das necessidades" (Ibid., p. 225). Nós todos vamos ao mercado para oferecer o que temos (trabalho ou bens) em troca do que necessitamos. Por outro lado, o homem neoliberal vai ao mercado, como formula Foucault, "sendo para ele mesmo seu próprio capital, seu próprio produtor, a fonte de seus rendimentos" (Ibid., p. 226). Seja vendendo, fazendo ou consumindo, ele investe nele mesmo e produz sua própria satisfação. A competição, e não a troca, estrutura a relação entre capitais, e a apreciação do capital pelo investimento estrutura a relação de qualquer entidade capital consigo mesma.

O reconhecimento de Foucault dos conceitos variáveis da economia em geral e do homem econômico em particular é extremamente útil para entender a peculiaridade das conceptualizações neoliberais de ambos. No entanto, como explanarei em breve, a falta de algumas características em seu relato o impede de extrair, deste reconhecimento, suas consequências para a vida política contemporânea e para os sujeitos políticos.

O que é o homo oeconomicus? Dizer que ele concebe o homem como fundamentalmente conduzido e orientado por preocupações econômicas reclama duas questões cruciais. Primeiro, há a questão do 
fora constitutivo do homo oeconomicus. Toda imagem do homem é definida em contraposição a outras possibilidades - por conseguinte, a ideia do homem como fundamentalmente econômico é traçada em contraposição à sua ideia como um ser fundamentalmente político, afetivo, religioso, ético, social, moral, tribal ou outro. Mesmo que uma imagem se torne hegemônica, ela se configura frente a uma gama de outras possibilidades - debatendo com elas de forma tácita, mantendo-as à distância ou subordinando-as. Assim, não é suficiente saber que os humanos direcionam-se ou motivam-se pela economia - temos de saber o que isso exprime em não sermos e, em especial, o que tem sido descartado, o que definitivamente não somos.

A segunda questão, exigida pela resposta simples, diz respeito à forma e aos conteúdos atribuídos ao econômico. Isto é, o que o homo oeconomicus é depende de como se concebe e posiciona a economia em relação a outras esferas da vida, lógicas, sistemas de significação e campos de atividade. ${ }^{5}$ Timothy Mitchell nos recorda, em Rule of Experts [O domínio dos experts], que "a economia", um substantivo com artigo definido, um substantivo dando nome a um domínio objetivo em vez de um processo ou prática, passou a existir apenas nos anos de 1940 e 1950 (MITCHELL, 2002). ${ }^{6}$ Antes dessa época, "economia" (sem o artigo) referia-se a buscar um fim desejado com o mínimo gasto possível de meios, o mais próximo, hoje, da noção de eficiência ou parcimônia. (Um vestígio persiste em nossa língua como quando dissemos "esse é um método bastante econômico" ou fazemos referência a "economizar" em nossos gastos ou à "classe econômica" em um avião.) Assim, quando unido ao adjetivo, "político", Mitchell argumenta, "economia" identificava um modo particular de governar as relações da comunidade, não uma estrutura de produção e troca, tampouco o domínio do mercado ou a esfera da vida material. De fato, somente quando o artigo definido desliza para lá é que "a economia" é lançada como uma estrutura autocontida, aquela na qual a produção ganha a sua própria esfera autônoma (Ibid., p. 81). Compare isto com a origem etimológica de economia, oikos, que identificava para os gregos antigos o espaço/lugar da casa, e não a vida material enquanto tal, nem o mercado, nem a economia.

Em suma, a identificação e reificação de "a economia" como um objeto distinto é recente, e essa novidade influencia o que pensamos e ouvimos quando dizemos "homo oeconomicus". De fato, o reconhecimento dessa novidade também poderia orientar nossa compreensão de frases como "os mercados estão instáveis" ou "insatisfeitos" ou "reagindo diante do temor da dívida espanhola". Ele também oferece perspectiva sobre o que está se desdobrando agora: embora continuemos a nos referir a "a" economia - sua atividade, saúde, crescimento de taxas, apertos - seu uso está se tornando anacrônico à medida que as fronteiras da economia enfraquecem por meio da disseminação neoliberal das métricas de mercado para outras esferas da vida e da atividade humana, um processo que Koray Caliskan e Michel Callon chamam de "economização" (CALISKAN e CALLON, 2009). ${ }^{7}$ Isso sugere que $a$ economia, longe de ser uma categoria trans-histórica, pode ter sido uma ocorrência breve do século XX. Quem e o quê, afinal, é o homo oeconomicus ao longo do tempo? Trata-se, com certeza, de um personagem bastante polimórfico.

A conceitualização do econômico e do caráter tomado para ser modelado em sua imagem requer, por conseguinte, atenção a sua historicidade e oposição ou adjacência constitutivas a outras órbitas de atividade. Também requer especificação de seus atores e suas dinâmicas e características centrais. A vida econômica é fundamentalmente caracterizada, como o fez Smith, pela divisão de trabalho e troca, ou como julga Marx, pelas relações de classe de capital e trabalho (MARX, 1978c)? Seria, como para Ricardo, uma operação de distribuição (RICARDO, 1973)? Ou, como para Malthus, um trabalho em e sobre demografia (MALTHUS, 1993)? Ou, como insiste Keynes, estaria enraizada no problema do emprego e na eficiência marginal do capital, ou como os macroeconomistas de hoje diriam, em um mecanismo vasto de dinamismo e integração sociais (KEYNES, 1936)? Ou, como os diversos neoliberalismos o entenderiam, a vida econômica, melhor definida como um mercado de entidades capitais concorrentes, é grande ou pequena (BECKER, 
1964)? Os meios particulares nos quais se constrói e concebe o econômico - suas fundações, elementos constitutivos e dinâmicas - também determinam como seus sujeitos são moldados, por exemplo, como trabalho ou poder de trabalho; commodities ou seres de troca; consumidores, clientes, empreendedores ou capital humano autoinvestidor.

Quem e o que é o homo oeconomicus - o que o direciona e recompensa, em qual contexto ele opera, sua relação consigo e com os outros - depende do amoldamento da vida econômica em tempo e espaço determinados. Embora Foucault esteja atento a esse problema (afinal, aprendemos a pensar assim com ele), há dois aspectos importantes nos quais ele deixa de levar a cabo todas suas implicações nas aulas sobre neoliberalismo. Primeiro, através dos esquemas clássicos e neoliberais, Foucault mantém como uma constante a noção de que o homo oeconomicus é um homem de interesse ou, como ele expressa, "um sujeito de interesse dentro de uma totalidade que o escapa e que não obstante encontra a racionalidade de suas escolhas egoístas" (FOUCAULT, 2004, p. 278). De acordo com Foucault, o que "caracteriza o homo oeconomicus" é ele ser conduzido pelo interesse e "sua ação ter um valor multiplicador e benéfico pela intensificação do interesse" (Ibid., p. 276). Como irei argumentar, não penso que "interesse" capture adequadamente o ethos ou subjetividade do sujeito neoliberal contemporâneo; esse sujeito é integrado de modo tão profundo e, portanto, subordinado ao objetivo imperante do crescimento macroeconômico a tal ponto que seu próprio bem-estar é sacrificado com facilidade a esses propósitos maiores.

Além disso, a ideia e prática de responsabilização - que coage o sujeito a se tornar um autoinvestidor e autoprovedor responsável - reconfigura o comportamento correto do sujeito de alguém conduzido naturalmente para interesses satisfatórios para alguém forçado a se envolver em alguma forma particular de autossustento que se mescla à moralidade do Estado e da saúde da economia. ${ }^{8}$ Por isso, o neoliberalismo difere do liberalismo econômico clássico não apenas no sentido de que deixa de ser o que Smith formulou como uma "mão invisível" a forjar um bem comum a partir das ações individuais e autointeressadas, e não somente porque o naturalismo é substituído pelo construtivismo, embora ambos sejam o caso (SMITH, 1976a, p. 477). De igual importância, reconciliar interesses individuais com nacionais ou outros coletivos não é mais o problema contemporâneo que se entende como a ser resolvido pelos mercados. Em vez disso, a noção de indivíduos que perseguem naturalmente seus interesses tem sido substituída pela de produção através da condução de cidadãos responsabilizados, que de forma apropriada autoinvestem em um contexto de vicissitudes e necessidades macroeconômicas que tornam todos esses investimentos práticas de especulação. O homo oeconomicus é feito, não nasce como tal, e opera em um contexto repleto de risco, contingência e potencialmente de mudanças violentas, de bolhas especulativas e desastres de capital ou de câmbio até a dissolução industrial em grande escala. Dito de outra forma, em vez de cada indivíduo perseguir seu próprio interesse e sem querer gerar benefício coletivo, hoje o que se tem é o projeto de crescimento macroeconômico e aumento de crédito aos quais os indivíduos neoliberais estão atrelados e com os quais sua existência enquanto capital humano deve se alinhar se quiserem prosperar. Quando indivíduos, empresas ou indústrias constituem um fardo nesse quesito ao invés de uma contribuição, eles podem legitimamente ser eliminados ou reconfigurados - por meio de downsizing, licenças, terceirização, cortes de benefícios, cotas de emprego obrigatório ou realocação de produção offshore. Nesse ponto, o trono do interesse sumiu e, no extremo, foi substituído pelo trono do sacrifício. ${ }^{9}$

Em suma, hoje o homo oeconomicus pode não ter mais o interesse em seu cerne [at its heart], de fato, pode nem ter mais um coração [heart]; iremos perseguir as implicações disso em breve. Esse é um caminho importante que a história de Foucault não apreende: tratar o interesse como a direção essencial e trans-histórica desse personagem nos impede de ver implicações importantes da mudança de uma formação liberal clássica para uma neoliberal, de Adam Smith e Jeremy Bentham para Gary Becker. 
O segundo limite na articulação de Foucault das dimensões originais do sujeito neoliberal contemporâneo diz respeito à ruptura deste sujeito com tensões cruciais do humanismo ocidental. Apesar de identificar as mudanças morfológicas no homo oeconomicus ao longo de três séculos, Foucault falha ao registrar o eclipse específico do homo oeconomicus na era contemporânea. Nas aulas do Collège de France, ele se refere à presença contínua do homo juridicus ou homo legalis e à existência heterogênea e ininterrupta dessas duas figuras com o homo oeconomicus. Assim, para Foucault, a cidadania moderna figura uma dupla persona, legal-jurídica por um lado, econômica por outro. Ele diz que há "o sujeito de interesse" e "o sujeito de direito" - o primeiro sempre "extravasa" o outro, sendo-lhe irredutível e submetido a uma lógica e forma de governança completamente diferentes (FOUCAULT, 2004, pp. 274 e 282). O "sujeito de direito", homo juridicus, deriva do que Foucault chama de "unidade totalizadora da soberania jurídica" e surge por meio dos limites específicos nessa soberania. Em outras palavras, o homo juridicus é um ser derivado ou deduzido da soberania do Estado, não de capacidades ou direcionamentos de base imaginados no ser humano - ele não guarda paralelo com os impulsos primários do homo oeconomicus. O homo juridicus se origina do poder constituidor da soberania, da sua produção de certos tipos de sujeitos, e da especificação da relação entre esses sujeitos e ele mesmo como aquela em que cada um tem alguns direitos. 10 "O liberalismo", diz Foucault, "adquiriu sua forma moderna justamente com a formulação dessa incompatibilidade essencial entre a multiplicidade não-totalizável de sujeitos econômicos de interesse e a unidade totalizável da soberania jurídica” (Ibid., p. 282).

Para Foucault, então, existe um triângulo no liberalismo moderno cujos três ângulos são soberania (Estado), economia e sujeito; a problemática relacionada a eles é quem domina, quem limita o poder, quem tem qual jurisdição, quem ou o que é reconhecível ou tocável por quem, e quem não é (Ibid., pp. 282-97). Os elementos-chave dessa problemática são limites, domínios, conhecimento, cognoscibilidade e intervenções, e suas tensões constitutivas são o despotismo versus o domínio da lei, limites no soberano versus liberdade individual, conhecimento e domínio soberanos versus a "crítica da razão governamental" apresentada pela economia neoliberal.

Certamente esse esquema das tensões constitutivas da governabilidade liberal é interessante e profícuo. Mas também é limitado e extremamente comportamental. O que falta nesse quadro (além das configurações variáveis da relação família-indivíduo que colocariam o gênero em primeiro plano) é o sujeito que podemos chamar de homo politicus, sujeito animado pela e para a realização da soberania popular, assim como por sua própria soberania individual - o sujeito que fez as revoluções francesa e americana e a quem a constituição americana fez nascer, mas também o sujeito que conhecemos como o indivíduo soberano que governa a si próprio. Talvez Foucault nunca tenha de fato levado esse sujeito a sério, ou talvez Foucault o via tirado de cena logo no início da modernidade - pelo soberano, pela economia ou mais cedo ainda pela Igreja. Ou talvez Foucault o via como uma personagem meramente episódica e não rotineira no triângulo da governabilidade moderna delineado por ele. Não obstante, é estranho que a soberania para Foucault permaneça aliada ao Estado de forma tão estreita e nunca circule entre as pessoas - é quase como se ele esquecesse de cortar a cabeça do rei na teoria política.

Seja como for, o homo politicus não é um personagem da história foucaultiana, o que tem consequências tanto para a compreensão do que está em jogo na ascensão da razão neoliberal, quanto para as perspectivas de contestação de seu quadro de valores. O restante deste capítulo tem como objetivo compensar essa ausência. Minha proposta é que o homo politicus, embora débil, existiu lado a lado com o homo oeconomicus ao longo de uma grande porção da modernidade e que a forma e os conteúdos de ambos mudam constantemente, em parte, mas não somente, por meio de sua relação mútua. Também argumentarei que o homo politicus é a vítima mais importante da hegemonia da razão neoliberal, sobretudo porque sua forma democrática seria a arma 
principal contra tal manifestação da razão como uma racionalidade governante, o recurso para opô-la a outro conjunto de exigências e outra visão existencial. Não há só um "sujeito de direito e um sujeito de interesse", como Foucault entenderia, mas um sujeito da política, um sujeito demótico, que não pode ser reduzido a direito, interesse, segurança individual ou vantagem individual, embora, é evidente, essas características tisnem por toda parte sua paisagem e linguagem no período moderno (Ibid., p. 274). Esse sujeito, o homo politicus, forma a substância e legitimidade do que seja lá o que a democracia possa significar para além da garantia de provisão individual de fins individuais; esse "para além" inclui igualdade e liberdade políticas, representação, soberania popular, deliberação e julgamento sobre o bem público e o comum. Apenas ao fim do século XX, o homo oeconomicus (em sua iteração tipicamente neoliberal) tomou finalmente o melhor do homo politicus, usurpando seu território, condições e objetos, tanto na figura do humano quanto na da entidade política. Se esse processo tivesse de se completar, se o homo politicus de fato fosse subjugado, ele iria obscurecer o globo contra todas as possibilidades de um futuro democrático ou justo.

\section{A morfologia variável do homo oeconomicus e homo politicus}

No começo, havia o homo politicus: o homem era "por natureza um animal que pretendia viver na polis" (ARISTÓTELES, 1946, 1.7.9). A atribuição antiga de uma natureza política ao homem não se referia, como se pensa hoje com frequência, ao desejo humano de poder ou conivência, mas a viver junto em uma maneira de governar deliberada; ao autogoverno em uma associação estabelecida que contém, ou até mesmo excede, demandas básicas e ao lugar da liberdade e da perfectibilidade humanas na vida política. Como narra Aristóteles, o fenômeno da polis ela mesma - complexa internamente e diversa externamente ao longo de várias evidenciações - exprime as muitas maneiras pelas quais os seres humanos distinguem-se de outros animais e deuses. É aí que percebemos e desenvolvemos nossas capacidades distintivas para associação, fala, lei, ação, julgamento moral e ética. Por conseguinte, nossa natureza política emerge das capacidades distintivamente humanas de reflexão moral, deliberação e expressão, de um lado, e de formas múltiplas de produzir associações, de outro. Reflexão moral e produzir associação - essas são as qualidades que geram nossa politicidade [politicalness]. Os dois são narrados pelo próprio Aristóteles na medida em que julgamentos morais mediados linguisticamente permitem aos humanos ordenar e governar suas associações - da família até o Estado - conforme deliberações sobre o bem (Ibid., 1.2.13). Eles também se relacionam por conta de sua contribuição para a "autossuficiência": enquanto seres de dependência mútua, humanos que vivem em uma polis podem desfrutar da justiça, bem como da capacidade de perseguir a "vida boa", isto é, a vida que envolve capacidades distintivamente humanas e excede a preocupação com a mera sobrevivência (Ibid., 1.2.14).

A convicção de Aristóteles de que o homem é por natureza um animal político, que, com seus iguais, "governa e é governado em alternância”, complica-se, porém não é desfeita, por sua descrição dos pré-requisitos do homem político - escravidão e propriedade privada no oikos. Ao naturalizar a escravidão de modo infame enquanto instrumento de aquisição (crematística), Aristóteles distingue e abarca um certo instrumentalismo que poderia facilmente sair de controle. Tanto o mestre quanto os subordinados arriscam ser definidos por completo pelas relações que poderiam permitir a geração de riqueza doméstica tornar-se seu próprio fim. Muito do livro I da Política pode ser lido como a formulação de uma cerca moral contra esse perigo, aquela que se volta incansavelmente contra o homo oeconomicus, designando-o de forma essencial como não natural e perverso. Assim é o que parece.

Para Aristóteles, o lar apresenta tanto relações de comando quanto de produção. Assim, ele tem tanto uma dimensão ético-política quanto econômica e, embora Aristóteles alinhe as duas com cuidado, despende mais atenção à primeira que à segunda. As relações de autoridade, pedagogia e comando entre cidadãos e suas esposas, filhos e escravos são especificadas com cuidado em formas que os estabelecem como benéficos 
tanto para os que governam quanto para os que são governados. Mesmo o escravo, tomado como uma peça da "propriedade viva” do mestre e um "instrumento" da casa, é beneficiado pelo comando do mestre, da mesma forma que o corpo é beneficiado pelo comando da alma. Aristóteles também desenvolve as normas da crematística em conformidade com a natureza e, ademais, fornece uma ontologia naturalista para as relações da casa, da aldeia e da polis, ou, dito de outro modo, para "o econômico" e "o político".

Embora o lar tenha uma função moral, que envolve o exercício apropriado de autoridade sobre os inferiores, e uma função econômica, que provê para si mesmo, a segunda é limitada tanto pela primeira quanto em geral. Governar sempre deve tender para o bem do governado e a riqueza nunca tem de se tornar seu próprio fim. Na verdade, como diz Aristóteles, "existe um limite fixado [para a propriedade de que necessita o tipo de administração doméstica]. Todos os instrumentos dos quais todas as artes necessitam são limitados, seja em número e tamanho, pelos requisitos dos tipos que servem” (Ibid., 1.8.15). Aristóteles continua a chamar criticamente de "não natural" a riqueza que é acumulada para seu benefício próprio e, sobretudo, por usura (Ibid., 1.9.1). Ele distingue com nitidez os objetivos e ethos do abastecimento ou satisfação de necessidades domésticas do mundo do mercado de troca, mesmo quando os dois estejam, na prática, quase imbricados (Ibid., 1.9). Aristóteles procura separar as duas práticas da crematística não só de acordo com seus propósitos, mas em conformidade com o lugar onde ocorrem - no lar ou no mercado - embora, de novo, praticamente não possam ser separados dessa forma; não sendo autossuficientes, a maioria dos lares tem de participar em mercados em alguma medida, e é por isso que a aldeia faz parte do desenvolvimento teleológico em direção à polis.

Então o que impedirá que os lares se tornem locais de acumulação e autointeresse familiar (a preocupação de Platão na República), e não de satisfação de necessidades? O que impedirá que cidadãos proprietários orientados à crematística como uma ordem de pré-requisito para a satisfação de necessidades para a vida boa não a concebam como um fim em si mesmo? Em suma, o que impedirá o surgimento do homo oeconomicus? O primeiro passo de Aristóteles nessa direção é o de favorecer o escambo no lugar das relações de mercado, pois o escambo aplaca necessidades, ao passo que os mercados dirigem-se ao lucro. Contudo, mesmo para o suprimento de necessidades, Aristóteles reconhece a inevitabilidade da troca baseada em moeda que resulta do comércio à distância (Ibid., 1.9.7). Procura, portanto, outras maneiras de conter os impulsos gerados pela presença do mercado; um deles é o moral e o outro, ontológico.

A tática moral consiste no seguinte: ao reconhecer que o envolvimento com a troca movida por lucro pode facilmente estimular o desejo pela riqueza em si mesma, Aristóteles denomina tal prática de "não natural" justamente porque seu fundamento é a moeda e a troca, e não o uso e a necessidade, e porque "o ganho resultante não se produz naturalmente [com os frutos da terra e os animais], mas se produz para uns a expensas de outros" (Ibid., 1.10.4). O caráter não natural do dinheiro, do lucro e da riqueza provinda do comércio torna-os moralmente inferiores à preocupação doméstica com o "suprimento da subsistência". É fácil perceber nessa depredação moral do homem no comércio um esforço para conter e restringir o desejo econômico, para mantê-lo subordinado ao propósito da provisão (valor de uso), de modo que ele não desenvolva energias e finalidades próprias.

Outro grilhão que Aristóteles coloca nos impulsos gananciosos envolve a separação ontológica das preocupações dos cidadãos proprietários da crematística do mercado:

É que, a riqueza e a arte de adquirir bens segundo a natureza, são muito diferentes do que vimos. Estas referem-se à administração da casa, a crematística comercial gera dinheiro, embora não de qualquer modo, mas por via de troca de bens. E esta troca de bens parece que se refere ao dinheiro devido a este ser meio e finalidade de troca. A riqueza adveniente deste modo de adquirir bens é ilimitada (Ibid., 1.9.12-13). ${ }^{11}$ 
Aristóteles prossegue especificando a diferença entre a crematística doméstica e sua forma comercial enquanto diferença entre a ansiedade diante das condições de vida e o bem-estar; a acumulação e o sustento; os deleites físicos e o provimento de uma "vida boa" (Ibid., 1.9.15-17). Ao término de sua discussão, ele não deixa dúvidas de que, ainda que os objetos, as atividades e inclusive as pessoas sejam as mesmas, os dois domínios são opostos: um é natural, o outro não; um é moralmente superior, o outro é moralmente vil; um é necessário, o outro não; um é limitado, o outro é ilimitado (Ibid., 1.9.15-18). "Por oposição a este tipo de crematística, a arte de adquirir bens que se encontra relacionada com a administração da casa, tem um limite, pois a sua função não é a aquisição ilimitada de dinheiro" (Ibid., 1.9.14). Sendo assim, ainda que o lazer gerado pela crematística doméstica seja essencial à vida ética e política do homem, o cultivo deste pré-requisito restringe-se com rigidez a seu propósito.

Em suma, mais do que simplesmente teorizar a natureza do homem como política, Aristóteles trabalha de forma assídua para impedir que o homo oeconomicus ganhe existência e designa tal criatura de "não natural" e "perversa". Se Aristóteles cria para si um problema contra o qual luta - a proximidade da aquisição da casa aos demais tipos - ao defender a propriedade privada, as famílias e a escravidão em contraposição à tentativa de Platão de aboli-las, trata-se de um problema com o qual ele lida de forma direta. A formulação do homem como essencialmente político - feito para viver na polis, participar do seu governo, deliberar sobre as ações apropriadas e as relações justas para cada esfera da vida - é o fundamento para manejar esse problema. O homem é político porque é uma criatura moral, gregária e detentora de linguagem que utiliza tais capacidades para governar a si próprio e aos outros. Mesmo durante os longos séculos entre a antiguidade e a modernidade, quando tais capacidades impregnaram-se pelo projeto de servir a Deus, o homem continuou a se definir por elas (LAVAL, 2007 e HIRSCHMAN, 1977).

Pensa-se amiúde que o homo politicus começou a esmorecer no século XVII, à medida que o interesse pela propriedade e pelas coisas, em especial, tornou-se preponderante, tendo então falecido no século XVIII, quando o crescimento do capitalismo e sua prevalência sobre a vida pública nos reduziram àquilo que $\mathrm{C}$. B. Macpherson celebremente caracterizou de individualistas possessivos, "proprietários de nós mesmos ou de capacidades que nada devem à sociedade", estando esta reduzida, em larga medida, às "relações de troca entre proprietários" (MACPHERSON, 1962, p. 3). Essa é a história, como Foucault diria em outro contexto, que contamos a nós mesmos e, de fato, é esta a história contada por pensadores que vão de Rousseau a Marx e Hannah Arendt, de Antonio Gramsci a Jürgen Habermas, de Leo Strauss a Sheldon S. Wolin.

Decerto, A riqueza das nações, de Adam Smith, marca a transformação radical do "ser feito com vistas à associação política", descrito no primeiro livro da Política de Aristóteles. Na obra de Smith de 1776, o que distingue o ser humano dos deuses e das bestas é nossa propensão única para fazer acordos [to make deals], que Smith também caracteriza como origem da divisão do trabalho, uma divisão que está no fundamento de toda sociedade e civilização. Para Smith, não é a ação, o discurso, o raciocínio moral, a deliberação ou a capacidade de associação que sinalizam nossa singularidade, mas sim a capacidade de efetuar transações mercantis; não é a autodeterminação política e coletiva que serve como base e indício de nossa existência civilizada, mas a produção de riqueza gerada pela divisão de trabalho (SMITH, 1976a). Marx especifica o assunto ainda mais: o próprio trabalho, e não apenas sua divisão, nos distingue como espécie e cria o mundo (MARX, 1978c). Sendo assim, a história parece se confirmar: na vida intelectual e prática, o homo oeconomicus tomou o posto do homo politicus. Aristóteles foi invertido, quando não enterrado.

No entanto, se tomarmos como ponto de partida a apreciação de Foucault dos discursos polivalentes e das histórias heterogêneas, o surgimento do homo oeconomicus não precisa significar que o homo politicus desapareceu, ou ainda, que ele foi subordinado. Com efeito, se retornarmos a Smith, podemos ver que, na 
primeira vez em que apresenta nossas propensões para negócios e permuta, ele toma o cuidado de estipular nossa capacidade de efetuar transações mercantis como uma qualidade humana dentre outras, que não seria nem primária, nem imediata. Em vez disso, Smith fundamenta tal qualidade na nossa capacidade para a linguagem, a deliberação, o cálculo e uma determinada soberania do Eu em um mundo cada vez mais interdependente. Imediatamente após apresentar a propensão para os negócios, a permuta e a troca, Smith diz ser menos provável que isso seja um "princípio original" da natureza humana do que "uma consequência necessária das faculdades da razão e do discurso" e da nossa complexa e singular interdependência enquanto espécie. ${ }^{12}$ A linguagem e o cálculo facilitam a efetivação de acordos [deal making], que é ela própria animada pela intensa necessidade que temos uns dos outros. Nós barganhamos, diz ele, para proporcionar vantagem aos que suprem nossas necessidades, algo que não se requer e que tampouco é possível para as criaturas mais autárquicas do mundo animal. Em resumo, ainda que seja certo que o homo oeconomicus opere de acordo com o interesse, segundo Smith, a forma de interesse não é nem primordial, nem anistórica. O interesse nasce da necessidade em meio à interdependência e é facilitado pela linguagem e razão que geram relações de mútuo benefício por meio da troca. Longe de ser uma criatura de meros (ou puros) interesses, o homo oeconomicus de Adam Smith está baseado em, e impregnado de, deliberação, autodireção e comedimento - todos ingredientes básicos da soberania. Ademais, como os leitores da Teoria dos sentimentos morais bem o sabem, o autointeresse não é nem de longe o nódulo exclusivo ou central da sua descrição da natureza humana. ${ }^{13}$

Se voltarmos à tese de Timothy Mitchell de que a "economia política”, em sua origem, referia-se ao governo (econômico) da comunidade política, ao invés de se referir à política ou aos poderes da vida econômica, então, a ascensão da economia política no século XVIII permanece compatível com a suposição de uma soberania do político perante o econômico. Ela permite a primazia continuada do político tanto no Estado quanto no homem, sua versão em miniatura - sendo tais soberanias gêmeas a continuação moderna da antiga homologia cidade-alma. De fato, o argumento de Smith em prol do laissez-faire baseia-se na noção de que o Estado pode escolher suas relações com a atividade econômica da sociedade que emerge a partir do poder que os indivíduos têm para efetuar transações de mercado; ele pode pender para o mercantilismo ou manter-se como um Estado capitalista, mas não há dúvidas sobre o que é soberano. Dito de outra maneira, na medida em que tanto o homem quanto o Estado tornam-se cada vez mais afetados pela produtividade, salários e riqueza, ambos se tornam econômicos em sua maneira de governar, porém isso ainda não os torna econômicos em identidade e forma. A proeminência das características econômicas do homem no pensamento e prática modernos reconfigura, mas não extingue, suas características políticas - novamente, estas incluem a deliberação, o pertencimento, a ambição pela soberania, a preocupação para com o comum e para com a relação que se tem com a justiça no comum. Isto se evidencia o suficiente no fato de as lutas dos séculos XVIII, XIX e XX por emancipação política, sufrágio, igualdade e, em momentos mais radicais, por uma soberania popular efetiva não poderem ter emergido do homo oeconomicus e não se formularem em uma linguagem econômica. Os interesses de classe, é claro, perfilam e interseccionam as reivindicações políticas, mas o homo politicus não foi suplantado pela imagem do homem como partícula de capital.

Alertar para a persistência, ainda que diluída, do homo politicus ao longo da modernidade situa grande parte do pensamento político moderno sob uma luz diferente daquela presente nas discussões de Foucault sobre o liberalismo clássico, nas aulas do Collège de France. Ela destaca, por exemplo, a intensa qualidade política do estado de natureza lockiano antes da propriedade ser introduzida. Nesta condição primeva, tal qual Locke conta no Segundo tratado, não visamos apenas à autopreservação, mas também somos responsáveis por discernir, julgar e executar a lei de natureza em nome do comum (LOCKE, 1993). Antes do contrato social, temos em nossas mãos, e como parte de nossa obrigação moral para com Deus e os outros, os poderes de executar e de fazer cumprir a lei de natureza em nome da justiça comunal e da 
preservação. Tais poderes e orientação marcadamente políticos são o que eventualmente iremos conferir às instituições políticas quando firmamos o contrato social. É claro que a primazia política no estado de natureza de Locke é reduzida por meio da intensificação do interesse individual que a propriedade introduz nesse estado. Todavia, esse aspecto político nunca se separa por completo do projeto do contrato social ou de seu propósito e legitimidade. ${ }^{14}$ Longe de nos dar uma imagem do homem como um ser movido de forma implacável pelo interesse individual, Locke mostra a tensão entre semelhante impulso e o homo politicus (e até mesmo o perigo imediato que a ascensão do homo oeconomicus representa para o homo politicus), tensão esta que Rousseau tornaria explícita.

Para Rousseau, com efeito, nós somos livres, soberanos e autolegisladores apenas quando nos juntamos com outrem para ditar os termos por meio dos quais viveremos juntos (ROUSSEAU, 1968). Ao ceder a soberania que têm sobre si próprios, aqueles que permanecem escravos do instinto ou do interesse individual renunciam tanto a sua liberdade quanto a seu caráter humano. Para Rousseau, os humanos são as únicas criaturas capazes de gerar ordens complexas de dominação das suas necessidades, de se escravizar ao conceder rédea solta para o homo oeconomicus, deixando-o dominar suas personalidades, relações sociais e política: eis a essência da crítica de Rousseau ao liberalismo nascente. Para Rousseau, portanto, o cultivo árduo e deliberado do homo politicus (que de modo algum é o homo juridicus ou homo legalis) é o único antídoto para este perigo. O homo politicus - compreendido como soberano de si por meio da soberania coletiva - deve literalmente subjugar a criatura de autointeresse absorvida nela mesma. Do contrário, não apenas caímos no egoísmo, narcisismo e superficialidade, como somos dominados pelas relações sociais e regimes gerados pelo interesse desenfreado. Embora a crítica distintiva que Rousseau faz da modernidade e do liberalismo o situe fora do mainstream, a oposição que ele articula entre um regime de interesse e um regime de soberania popular e liberdade mantém-se como uma tensão no pensamento dos séculos posteriores.

O sujeito hegeliano, por exemplo, consome-se na universalidade do Estado e da vida política, não na particularidade da sociedade civil e da vida ética (HEGEL, 1952). A liberdade política, ao invés daquela carregada de interesse, a liberdade ligada à igualdade, ao reconhecimento mútuo e à identificação no pertencimento - é assim que o homem se realiza e se aperfeiçoa para Hegel. A importância do homo politicus no pensamento político moderno também explica a obsessão de Marx, em seus escritos de juventude, pela figura não realizada do homem político soberano e sua crítica da condição periclitante do homem político na democracia constitucional (MARX, 1978a). Ela nos ajuda a entender por que, quando Marx se debate com os hegelianos e as ficções do estado burguês, sua preocupação inicial não é com a desigualdade de classe ou a exploração, mas sim com o que ele acredita ser a liberdade ilusória e as noções empobrecidas de cidadania e de pertencimento oferecidas pelo constitucionalismo burguês. Do mesmo modo, sua crítica da Revolução Francesa diz respeito ao seu fracasso em realizar a luta por "Liberté, Égalité, Fraternité" que a animava (MARX, 1978b). Na sua avaliação da "emancipação política" - a concessão formal do direito ao voto a porções até então excluídas da humanidade -, constata o isolamento e impotência do indivíduo politicamente emancipado, sujeitado a poderes além do seu controle que perderam seus nomes políticos. Para Marx, o homem político é tanto um soberano fantasmagórico quanto um ser assombrado pelos seus próprios poderes políticos alienados, que passam a dominá-lo por meio dos poderes do Estado e da economia (MARX, 1978a).

A presença persistente do homo politicus aparece inclusive no sujeito utilitarista e calculador de Bentham, sujeito este saudado amiúde como um protótipo antigo do sujeito neoliberal. Bentham apresenta o sujeito utilitarista como um pequeno soberano, ainda que sob o domínio daqueles dois "mestres internos", o prazer e a dor; o que significa que nossa raison d'état individual não está inteiramente aberta para qualquer conteúdo ou significado, devendo necessariamente servir estes mestres (BENTHAM, 1969). Sim, os 
sujeitos benthamianos submetem-se a seus interesses, mas é o seu caráter político - seu propósito de suprir, gratificar e assegurar a si próprios - que os diferencia do sujeito neoliberal contemporâneo, e que também permite que a utilidade em Bentham passe, de modo tão fácil, de um princípio de conduta individual para um princípio de governo.

John Stuart Mill também nos caracteriza como pequenos soberanos que escolhem nossos meios e fins; a essência da humanidade consiste em fazer tais escolhas. Por conseguinte, em Sobre a liberdade, a questão-chave é onde demarcar a fronteira adequada entre a soberania individual e estatal, entre o direito público e a escolha privada. ${ }^{15}$ Eis uma questão política sobre um limite político que implica jurisdição, legislação, normas, punições e, sobretudo, esferas de ações. Noutras palavras, para Bentham e Mill, o sujeito pode pesar os custos e benefícios de cada fim e ação e pode ser regulado ou até coagido pelo Estado a aumentar suas capacidades e orientação produtivas. No entanto, o sujeito não é um capital humano fungível ou em circulação, instrumentalizado por si mesmo, pela sociedade, pela economia ou pelo Estado. É, antes, um soberano em miniatura, com uma variedade de fins possíveis. Ainda que, nesse momento da teoria política, o Estado conceba-se cada vez menos como o destino de nossa igualdade, liberdade e orientação à vida pública; ainda que ele esteja a se reconfigurar como um agente comportamental ou como aquilo que Foucault irá chamar de agente "biopolítico" que administra as populações e os seus desejos; ainda assim, o homo politicus subsiste na relação do sujeito com o seu Eu. Seu vestígio é aparente na nossa complexa realização da racionalidade que se requer para a soberania do Eu, necessária inclusive para sermos mestres, ao invés de escravos, de nossos desejos, assim como para resistir à interferência social e estatal nas nossas escolhas de vida.

Tampouco Mill, o economista político, apresenta um relato descritivo ou normativo do homo oeconomicus. Muito pelo contrário, no seu pequeno ensaio "On the Definition of Political Economy and the Method of Investigation Proper to It [Sobre a definição de economia política e seu método de investigação apropriado]", Mill deixa claro que os humanos são seres multifacetados e que, mesmo no âmbito econômico (que "não aborda o todo da natureza do homem [...], tampouco o todo da conduta do homem em sociedade"), podemos nos conduzir tanto pelo desejo ao lazer ou à procriação quanto pelo desejo de riqueza (MILL, 1967, p. 321). Talvez mais importante ainda seja a insistência de Mill de que a economia política "realiza uma abstração completa de qualquer outra paixão ou motivo humanos", operando, assim, com um sujeito fictício, necessário para se "obter o poder de prever e controlar o efeito [de certas causas]", mas fictício mesmo assim (Ibid, p. 322). Com efeito, escancarando a ironia das abordagens contemporâneas que o veem como o fundador do homo oeconomicus, Mill escreve: "nenhum economista político foi tão absurdo a ponto de supor que a humanidade realmente só se impulsiona [pelo] desejo de riqueza" (Ibidem).

Freud é com frequência interpretado pelos teóricos políticos como aquele que imbuiu o utilitarismo de complexidade psíquica: o princípio de prazer movido pelo $i d$ nos conduz a satisfazer nossos desejos de modo imediato, ao passo que a incorporação bem-sucedida do princípio de realidade do superego reprime e redireciona os impulsos, limitando inclusive a satisfação do ego em nome do corpo trabalhador e produtivo. Reprimido e redirecionado, o autointeresse originário nunca se anula, mas é combatido por meio da repressão e da sublimação, que o tornam mais pacífico, menos autodestrutivo e mais produtivo. Seja como for, os impulsos libidinais fulcrais e as economias psíquicas que, sem os eliminar, os redirecionam, mostram que Freud situava o interesse no cerne do homem civilizado? Deixando de lado a pergunta, recordemos que a imagem mais aterradora de Freud para os humanos na civilização não é a de animais refreados, mas a de "cidades conquistadas". O superego, ele afirma em Mal-estar da civilização, ganha domínio sobre nossos desejos perigosos ao enfraquecê-los, desarmá-los e vigiá-los "como uma guarnição sobre uma cidade conquistada" (FREUD, 2010, p. 84). Eis a homologia clássica entre alma e cidade; a 
imagem do homem e sua psique é inexoravelmente política. Ademais, a afirmação se dá em um texto que começa com a analogia da psique com a cidade de Roma: ambas mantêm suas verdades embaixo de camadas de ruínas, reconstrução e atividade contemporânea. Ambas, sobretudo, são projetos problemáticos e problematizantes da soberania.

Este foi um longo caminho para mostrar minha tese, um panorama a um só tempo muito envolvido com a história da teoria política e muito superficial em seu tratamento. A tese pode ser resumida deste modo: o homo oeconomicus certamente ascende e expande seu domínio na modernidade euro-atlântica, porém o homo politicus também permanece vivo e importante ao longo dessa época - pleno de reivindicações e expectativas, o lócus da soberania política, da liberdade e da legitimidade. Se Rousseau está praticamente sozinho ao reafirmar, com audácia, o predomínio dessa criatura na teoria contratualista, disto não se segue que o homo politicus estivesse ausente nos demais relatos. O homo politicus tampouco é apreendido de forma adequada por aquilo que Foucault chama de "homo juridicus" ou "homo legalis", que estão por demais atrelados à lei e aos direitos para capturar o ethos político e as reivindicações em questão. ${ }^{16}$ Isto significa que a subjugação do homo politicus pela racionalidade neoliberal contemporânea e a insistência de que, em cada esfera da vida humana, o que há são apenas atores políticos racionais, são ambas inéditas e, de fato, revolucionárias na história do ocidente. Antes de considerar as implicações deste evento com mais detalhe, gostaria de inquirir brevemente acerca do homo presente no homo oeconomicus - ele inclui ou exclui as mulheres? Não se trata de uma ampla investigação sobre o caráter colonial, racial ou gendrificado [gendered] do neoliberalismo capitalista, e sim uma investigação mais restrita sobre o status discursivo do trabalho familiar e feminilizado vinculado ao desalojamento neoliberal do homo politicus feito pelo homo oeconomicus. $\mathrm{O}$ homo oeconomicus e o capital humano têm um gênero? Há uma femina domestica estriando ou complementando invisivelmente tais figuras, ou seriam as esposas e as mulheres abarcadas por eles? ${ }^{17}$

\section{O gênero do Homo Oeconomicus}

Historicamente, mesmo quando sua masculinidade não era declarada de maneira explícita e a exclusão da mulher da categoria não era visível, o homo politicus, desde Aristóteles, até Kant e Hegel, assumia um comportamento e esfera de ação masculinista. Seja considerado como participante no governo do comum (Aristóteles), um virtu militar paralelo (Maquiavel), medida viril e de fortidão (Weber), ou simplesmente como autonomia, racionalidade e autossoberania (modernos), o homo politicus era quase sempre e expressamente masculino (BROWN, 1998; ELSHTAIN, 1993; FERGUSON, 1993; ZERILLI, 1994). ${ }^{18}$ Assim como, conforme Joan Scott nos lembra, as feministas revolucionárias francesas eram insultadas como monstruosas não apenas por suas demandas, mas pelo próprio fato de agirem, da mesma forma que os clamores pelo sufrágio feminino nos séculos XIX e XX eram amplamente injuriados como não naturais, além de desnecessários (SCOTT, 1997).

E sobre o homo oeconomicus? É raro economistas modernos e contemporâneos eminentes gendrificarem esta criatura, e quando ocasionalmente olham para a diferença sexual, em geral é para argumentar ou sugerir que a fisiologia é irrelevante para a forma, apesar de não o ser para o conteúdo dos animais escolhidos pelo mercado de modo racional. A criatura de mercado de Adam Smith, o capital humano de Gary Becker, os que no cotidiano fazem escolhas racionais - nenhum deles é especificado como sendo masculinos ou presumidamente dotados de gênero; até mesmo os neoliberais reconhecem a possibilidade de atributos específicos de gênero nos quais certos tipos de capital humano podem ser construídos (por exemplo, jogadores de futebol ou modelos de alta costura). De fato, o suposto personagem genérico da escolha racional e as supostas vantagens para todos de uma divisão do trabalho gendrificada entre a família e o 
mercado são os argumentos habilmente conjugados que animam o livro notável de Becker, $A$ Treatise on the Family [O tratado sobre a família].

Contudo, as feministas sabem bem que quando intelectuais presumem que seu objeto não possui gênero, isto está longe de ser a palavra final sobre o assunto. O homo oeconomicus não é exceção. Existem inúmeras dimensões sobre seu gênero e, por isso, inúmeros efeitos de sua ascendência e disseminação recentes. Começaremos com Margaret Thatcher, que durante sua campanha para neoliberalizar a Grã-Bretanha nos anos 1980 declarou de maneira infame: "Não existe isso de sociedade. Existem apenas homens e mulheres individuais [...] e suas famílias". Nossa preocupação é com a elipse, que não é de Thatcher apenas, mas que constitui, antes, um contínuo deslize neoliberal quando se trata da relação de sua unidade básica de análise, o indivíduo, que ele toma como necessário para uma unidade básica da sociedade, a família. Na verdade, o deslize de Thatcher ecoa próximo ao de Milton Friedman três décadas antes: "Como liberais", ele escreve em Capitalism and Freedom [Capitalismo e liberdade], "consideramos a liberdade do indivíduo, ou talvez a família, como o objetivo último no julgamento das organizações sociais" (FRIEDMAN, 1962, p. 12). De novo é o "talvez", a incerteza, que nos interessa. Mais tarde em seus trabalhos, Friedman insiste: "A unidade operacional última de nossa sociedade é a família, não o indivíduo" (FRIEDMAN, 1962, p. 63).

Aqui, a incoerência fundamental é óbvia o suficiente: se a família é a última unidade operacional, o local da liberdade, e a perspectiva da qual julgamos arranjos sociais, então o indivíduo não pode existir, e vice-versa. Uma forma de se explicar tal incoerência é que isso é ideologicamente conduzido: neoliberais que também são conservadores estão inclinados a ontologizar [ontologize] o indivíduo, a família heterossexual nuclear $e$ a diferença sexual. Eles buscam enraizar cada um na natureza, e não no poder, e não querem que a família seja a responsável por conferir gêneros aos indivíduos ou gerar desigualdades sociais. Naturalizam a família como naturalizam o indivíduo livre, e buscam os unir e reconciliar sem se preocupar com a lógica que realizaria ou não isto.

Outra forma de explicar a incoerência é por meio da subordinação de gênero tacitamente presumida: a liberdade individual repetida pelos neoliberais não se compromete com a família porque se refere apenas aos que vêm e vão livremente dela até o âmbito da liberdade de mercado, e não aos que exercem atividades ou trabalho não remunerados dentro dela. A história que se conta, em outras palavras, não é da perspectiva das famílias como conjuntos de indivíduos genéricos, mas a partir de um posicionamento social de longa data associado com os líderes masculinos dos lares. O deslize, então, ocorre precisamente porque esta perspectiva é renegada, mesmo quando a admitimos.

Tais explicações, contudo, oferecem apenas uma explicação do por que a oscilação entre indivíduo e família ocorre e não se dirigem ao que de fato se efetiva quando o neoliberalismo se torna uma racionalidade de governo. O que a oscilação entre indivíduo e família efetua, semioticamente, quando o homo oeconomicus é pensado como capital humano e subjuga todas as outras imagens do humano? Aqui temos que perguntar sobre a relação entre a reflexão posterior e ao objeto principal da frase de Thatcher. Conceitual e retoricamente, qual é o trabalho feito pela frase após a elipse na afirmação de que "existem apenas homens e mulheres individuais [...] e suas famílias"? Será que a família é posicionada como um pano de fundo, uma posse, ou uma extensão do indivíduo? É uma forma alternativa de descrever o indivíduo - em sua forma mais completa ou ampliada? Ou é uma associação à qual o indivíduo e sua conduta estão subsumidos? A família é algo que o homo oeconomicus "tem" ou que ele "é"? A família pertence a ele, ou ele à família? Ou a família engloba o indivíduo de maneira alquímica? Será que o neoliberalismo posiciona a família como parte do mercado, adjacente a ele, ou como uma esfera não mercantilizada que, mesmo assim, pode ser "economizada [economized]" no sentido de Caliskan e Callon, isto é, ordenada por e refratada pela razão econômica? 
Um segundo conjunto de questões emerge sobre o que mantém as famílias ou sociedades juntas em regimes neoliberais. Quando a razão neoliberal projeta cada humano, positiva e normativamente, em todos os domínios existenciais, como uma forma de capital empresarial autoinvestidor, responsável por si mesmo e que luta para fazer render seu valor vis-à-vis outras entidades do capital, como isto se comporta no domínio baseado em necessidades, explicitamente interdependente, afetivo e com frequência sacrificial das relações familiares? Como a família é levada a adquirir elementos de capital humano autoinvestidor? Como é possível pensar sobre sua "liberdade" ou "interesses" quando ela não é nem corporativa, nem individual? Gary Becker traz a noção de "renda psíquica" para explicar a mãe que se sacrifica pelos filhos e sofre privações econômicas por conta de seu compromisso "natural" de cuidadora (BECKER, 1991, p. 78). No entanto, Becker não aborda a questão do que mantém as famílias juntas, dada a falta de aderência social do capital humano em si. Quando existe apenas o homo oeconomicus e quando essa figura se compromete de modo implacável a apreciar seu valor individual, como a família (sem contar a ordem social) mantém-se unida?

Esta questão, aliada ao desejo de abordar motivações e investimentos - amor, lealdade, comunidade - que excedem o interesse e a valorização de si [self-enhancement], são os pontos de partida para críticos da escolha racional em economia, como Deirdre McCloskey (2005), Annete Baier (1997), Carol Rose (1990), Julie Nelson (1993 e 1995) e Paula England (2005). Cada uma das autoras argumenta que não existe a possibilidade das famílias ou sociedades se manterem juntas, que dirá funcionar, dentro do que McCloskey chama de "o paradigma hobbesiano" de seres humanos associais e não socializados que são motivados apenas por cálculos de posicionamento competitivo e sobrevivência (MCCLOSKEY, 2005, pp. 28-29). Essas críticas são complementadas por outros que, apesar de não estarem de maneira explícita preocupados com gênero, preferem o homo oeconomicus de Smith ao de Hobbes ou Bentham (DIXON e WILSON, 2012; HIRSCHMAN, 1984). Apesar da reputação popular de Smith em reduzir o homem a uma criatura de interesses, tais críticos sugerem que o filósofo escocês retratou uma figura mais complexa sobre a conduta, necessidades e virtudes humanas, inclusive dentro da vida econômica. McCloskey condensa as críticas ao homo oeconomicus contemporâneo, que para ela se baseia no homem hobbesiano e benthamiano, da seguinte forma:

O projeto de Smith era ético. Bentham o descarrilou e levou os economistas a pensarem somente em $P$, Prudência. Se a economia irá levar a sério a ideia de ser uma ciência "positiva" [...] e não constituir um mero caos de ideias precisas, ela deve retornar ao projeto de Smtih que via a Prudência dentro de um sistema de virtudes e vícios para uma sociedade comercial (MCCLOSKEY, 2005, p. 30).

Quando lidas em conjunto, estas críticas sugerem que uma forma de abordar o homo oeconomicus neoliberal é revelá-lo como uma representação distorcida, que repudia tudo o que o sustenta e todos os arranjos humanos. Nesta abordagem, o homo oeconomicus reduzido ao capital humano é falso: ele falha ao caracterizar a conduta que une famílias e sociedades, além de ser falsamente autônomo - sem necessidades e dependências. A crítica econômica feminista encontra na elipse de Thatcher, portanto, a repetição neoliberal de uma estória antiga - a do sujeito liberal, concebido a partir de um ponto de vista masculino e burguês, que é cultivado por fontes e qualidades que, elas mesmas, não constam na estória. Apenas os membros performaticamente masculinos de uma divisão sexual do trabalho gendrificada podem almejar ao tipo de autonomia que tal sujeito requer; a fim de unir a ordem social e familiar e prover as necessidades que este sujeito renega, outros (trabalhadores domésticos quer remunerados ou não) devem se orientar de forma diferente, em direção ao que Deirdre McCloskey (2005) chama de "ética da virtude [virtue ethics]" - o que Joan Tronto (1993) chama de "trabalho de assistência [care work]" e o que a socióloga Paula England (2005), por sua vez, denomina de "Eus' [selves] solúveis", ao invés de "separados". 
Entretanto, nosso enigma família-indivíduo - a questão de saber se seria a família ou o indivíduo a unidade de análise adequada para um mundo humano concebido como unidades competitivas de capital autossuficiente - ainda não se resolveu. Não estamos a lidar apenas com uma omissão analítica ou com o repúdio da natureza humana presente nas formulações liberais e neoliberais. Em vez disso, estamos a lidar com um mundo feito e governado por essa omissão e repúdio. Há duas maneiras de se pensar a concepção neoliberal do ser humano, cujo cuidado e investimento de si não podem ser obtidos por seus próprios meios, isto é, que depende de práticas invisíveis e outros não nomeados [unnamed others]. Uma delas consiste em pensar que o neoliberalismo comete um erro, que o homo oeconomicus é, ao mesmo tempo, mais multidmensional e dependente de entidades não capitalistas (ou seja, as mulheres) do que a sua ontologia sugere. Há certa pungência nessa crítica, porém não se trata de uma pungência radical. Ainda temos que questionar qual tipo de ordem gendrificada é produzida e reproduzida quando essa racionalidade prevalece, quando a valorização da atividade do capital humano individual se torna a norma governamental onipresente, quando, por meio da responsabilização, privatização, e desmantelamento da infraestrutura, junto com a disseminação da métrica neoliberal para todas as esferas existenciais, essa má ontologia se torna a verdade governante de todo o mundo Euro-Atlântico atual. O que ocorre, em suma, quando estamos a lidar não apenas com uma representação absurda e falsa das motivações e condutas humanas, uma má representação de quem somos e do que nos sustenta, mas com a produção do "real" por meio dessa representação dos propósitos, condutas e fins do ser humano? O que acontece quando os indispensáveis ethos e trabalhos necessários destacados por McCloskey, Tronto e England são ao mesmo tempo desqualificados e esmagados à medida que o homo oeconomicus se torna real em todos os sentidos da palavra?

Quando o homo oeconomicus se torna normativo em todas as esferas e a responsabilização e apreciação da vida humana se tornam $a$ verdade reinante da vida pública, vida social, vida laboral, bem-estar, educação e a família, existem duas possibilidades para aquelas posicionadas como mulheres na divisão sexual do trabalho, sobre as quais as ordens neoliberais continuam a depender para se reproduzir. Ou bem as mulheres alinham sua própria conduta a tal verdade, tornando-se homo oeconomicus, o que em todo caso torna o mundo inabitável, ou bem suas atividades e seu rumo como femina domestica se tornam a cola não declarada de um mundo cujo princípio governamental não o consegue manter unido - nesse caso, as mulheres ocupam seu antigo lugar como acessórios e suplementos não reconhecidos dos sujeitos masculinos liberais. Como provedoras de assistência para os outros nos lares, vizinhanças, escolas e locais de trabalho, as mulheres permanecem enquanto infraestrutura invisível de todo capital humano em desenvolvimento, maduro e desgastado - crianças, adultos, deficientes e idosos. Embora em geral não sejam coagidas, essa provisão e responsabilidade essenciais são teórica e ideologicamente encobertas no que se supõe serem as preferências que emergem naturalmente da diferença sexual, em especial da contribuição distinta das mulheres à reprodução biológica. Isso se formula, em suma, como um efeito da natureza, e não de poder. ${ }^{19}$

Essa conclusão é notícia velha na medida em que reverbera quarenta anos de críticas feministas ao liberalismo e capitalismo. A questão, então, é saber se a subordinação de gênero, teórica e politicamente invisível, é intensificada ou alterada de modo fundamental pelo neoliberalismo. Será que a ascensão do homo oeconomicus e sua formulação específica como capital humano gendrificam os arranjos sociais contemporâneos de modo mais intenso ou diferente do que seu precursor capitalista democrata-liberal?

Creio que a resposta é que a subordinação de gênero é ao mesmo tempo intensificada e fundamentalmente alterada. ${ }^{20} \mathrm{~A}$ intensificação ocorre por meio do encolhimento, da privatização, e/ou do desmantelamento da infraestrutura pública de apoio às famílias, crianças e aposentados. Tal infraestrutura inclui, mas não está limitada a programas escolares de qualidade e acessíveis, colônias de férias, sistema de saúde física e 
mental, transporte público, parques nas vizinhanças, centros de recreação, aposentadorias públicas, centros da terceira idade e seguridade social. Quando estas provisões públicas são eliminadas ou privatizadas, o trabalho e/ou o custo de seu fornecimento retorna aos indivíduos, sobretudo às mulheres. Dito de outra forma, a "responsabilização" no contexto da privatização dos bens públicos penaliza as mulheres à medida que elas são as que mais se responsabilizam por aqueles que não podem ser responsáveis por si. Neste aspecto, o familismo [familialism] é um requisito essencial, e não uma característica acidental, da privatização neoliberal de bens e serviços públicos.

É assim, pois, que o velho problema de gênero do liberalismo é intensificado pelo neoliberalismo. De que modo seria ele transformado por uma racionalidade político-econômica caracterizada apenas por capitais concorrenciais, grandes ou pequenos? Quando há apenas o capital (humano, corporativo, financeiro), o que desaparece analiticamente é o já marginal trabalho do lar, sua extensão como um trabalho voluntário cada vez mais indispensável em escolas e comunidades no contexto do desinvestimento público, e a divisão gendrificada de trabalho entre o mercado e o lar. Agora desprovidas de espaço na linguagem, visual e discursivamente ausentes da consciência pública, estas forças que moldam as vidas das mulheres são intensificadas pela privatização de bens outrora públicos e pelo encolhimento de benefícios do trabalho de meio período, no qual as mulheres, sobretudo, são empregadas. Assim, mesmo quando, como nos Estados Unidos, sua constituição na força de trabalho remunerada se aproxima a dos homens, e quando, como agora, obtêm maior nível educacional do que os homens após o ensino médio, as mulheres, na medida em que permanecem as maiores responsáveis por trabalhos assistenciais das mais diversas formas, ganham menos do que oitenta por cento de seus correspondentes masculinos ganham e são radicalmente sub-representadas no topo de todas as profissões. A linguagem do capital humano responsabilizado e individualizado não pode metabolizar, muito menos explicar, esta combinação de efeitos. Em vez disso, é mais comum se escutar afirmações como aquela do economista Lawrence Summer, que, como presidente de Harvard, especulou que a diferença de gênero [gender gap] na ciência acadêmica se explicava melhor por diferenças nas "habilidades inatas" (DILLON, 2005).

Dito de maneira diferente, enquanto o homo oeconomicus neoliberal é ao mesmo tempo gendrificado [gendered] e gendrificante [gendering] em sua ascendência e disseminação, isso é ilegível em seus próprios termos. A responsabilidade contínua das mulheres em prover assistência, nas mais variadas formas, dentro e fora do lar, significa que as mulheres ao mesmo tempo requerem a infraestrutura social visível que o neoliberalismo busca desmantelar por meio da privatização e são a infraestrutura invisível que sustenta um mundo supostamente formado por capitais humanos investidores de si. Portanto, a figura do homo oeconomicus não é simplesmente ilusória ou ideológica em sua negação das pessoas e práticas que constituem e sustentam a vida humana. Ao contrário, quando o homo oeconomicus se torna a verdade governante, quando organiza as leis, condutas, políticas e os arranjos cotidianos, os fardos e a invisibilidade sobre aqueles indivíduos e práticas excluídos se intensificam. ${ }^{21}$

Nossa atenção à omissão de Thatcher revela que a unidade de análise do neoliberalismo, o indivíduo genérico que se torna um capital humano responsabilizado, é, de forma pouco surpreendente, um macho social e masculinista [masculinist] dentro de uma ontologia econômica e de uma divisão de trabalho incessantemente gendrificadas. Isto de modo algum depende do fato de os homens serem "pais que ficam em casa", de as mulheres serem solteiras ou sem filhos, ou de as famílias serem queer. Dessa perspectiva, as famílias pertencem a estes indivíduos e não são mantidas para lhes gerar ou gendrificar, posicioná-los de forma diferente no mercado, ou sobrecarregá-los fora do mercado. Com apenas o capital humano competidor e valorador na estrutura, a desigualdade complexa e persistente de gênero é atribuída à diferença sexual, um efeito que o neoliberalismo toma como causa. Por conseguinte, uma mãe solteira empobrecida 
é enquadrada para falhar no projeto de se tornar um sujeito neoliberal responsabilizado, em particular nos contextos dos tipos de austeridade impostos pelo "confiscamento" orçamentário, nos Estados Unidos, ou pelos resgastes financeiros da União Européia na Europa do sul. Mais do que um fracasso, a liberdade oferecida pela racionalidade neoliberal (liberdade de regulação do Estado e da provisão de necessidades) é invertida, de maneira literal, em novas formas de subordinação de gênero à medida que as mulheres se mantêm como chefes provedoras de trabalho assistencial não remunerado e pouco apoiado fora do mercado, e são cada vez mais as fontes de renda única para si e suas famílias.

\section{A subjugação do homo politicus pelo homo oeconomicus}

De modo perverso, ao que parece, mas precisamente porque o homo politicus, em sua variante popular-soberana, é hoje menos gendrificado do que o homo oeconomicus sempre foi, retornemos agora à questão mais geral: quais são as implicações da subjugação neoliberal do homo politicus pelo homo oeconomicus? Enquanto o homo politicus é obviamente reduzido nas democracias liberais modernas, é apenas por meio da ascendência da razão neoliberal que o cidadão-sujeito se converte de um ser político em um ser econômico, e que o Estado passa, a partir de uma fundação jurídico-soberana, a ser refeito nos moldes de uma firma. Quando o neoliberalismo submete todas as esferas da vida à economização, seu efeito não se resume a diminuir as funções do Estado e do cidadão ou a aumentar a esfera da liberdade definida, economicamente, a expensas do investimento comum na vida e bens públicos. Antes, seu efeito é atenuar de maneira radical o exercício da liberdade nas esferas políticas e econômicas. Este é o paradoxo central, talvez até a artimanha central, da governança neoliberal: a revolução neoliberal se dá em nome da liberdade - mercados livres, países livres, homens livres - mas esgarça o fundamento da liberdade na soberania tanto dos Estados quanto dos sujeitos. Os Estados são subordinados aos mercados, governam para o mercado, e ganham ou perdem legitimidade de acordo com as vicissitudes do mercado; os Estados também se prendem nos caminhos divididos pelo impulso do capital para acumulação e pelo imperativo de crescimento econômico nacional. Liberados da busca de seu próprio melhoramento enquanto capital humano e emancipados de todas as preocupações e regulações advindas do social, da política e do comum ou coletivo, os sujeitos são inseridos nas normas e imperativos da conduta de mercado e integrados nos propósitos da firma, indústria, região, nação ou constelação pós-nacional aos quais sua sobrevivência está atrelada. Em uma repetição fantasmagórica da irônica "dupla liberdade" que Marx designou como o pré-requisito para que os súditos feudais fossem proletarizados na aurora do capitalismo (liberdade de posse dos meios de produção e liberdade para vender sua força de trabalho), uma nova dupla liberdade - do Estado e de todos os outros valores - permite que a racionalidade mercadológica-institucional se torne a racionalidade dominante que organiza e restringe a vida do sujeito neoliberal. É claro que isto se observa também na relevância dos modelos e métodos econômicos, disseminados por todas as ciências sociais, que vêm se tornando dominantes de modo notável na ciência política, mas ganhando terreno igualmente na antropologia e sociologia. Dentro da política, cultura, e sociedade, e por isso dentro das disciplinas que as estudam, há apenas o homo economicus.

Quando o homo politicus também se situava em um estágio liberal democrático, a liberdade, concebida minimamente como autogoverno e, de maneira mais robusta, como participação no governo do demos, era fundamental para a legitimidade política. Porém, ao perder sua morfologia propriamente política e, junto com ela, o manto da soberania, a cidadania não apenas perde sua orientação ao público e aos valores consagrados por, digamos, constituições, como também cessa de carregar a autonomia kantiana que subjaz a soberania individual. Devemos, aqui, lembrar a promessa liberal-democrática fundamental desde Locke, qual seja, a de que a soberania popular e a individual se consolidam mutualmente. Posto de maneira inversa, o homo politicus na modernidade, a um só tempo, enraíza-se na soberania individual e sinaliza a promessa 
do respeito social, político e legal por ela. Quando o homo politicus esmorece e a figura do capital humano toma seu lugar, não mais autoriza-se cada um a "buscar seu próprio bem da sua própria maneira", tal qual Mill elaborou de maneira célebre a questão. Não há mais uma questão aberta do que desejar para a vida, ou de como se pode querer modelar o Eu. Capitais humanos, como todas as outras formas de capital, são constrangidos pelos mercados, tanto em termos de insumos quanto de produtos, a se comportar em formas que irão superar a concorrência e a se alinhar conforme as boas avaliações sobre a provável direção desses mercados. Além disso, não importa o quão disciplinado e responsável seja, o fluxo de mercado e a contingência podem súbito trazê-lo a um destino sombrio. ${ }^{22}$

A hegemonia do homo oeconomicus e a "economização" neoliberal do político transformam tanto o Estado quanto o cidadão, visto que ambos se convertem, em identidade e conduta, de figuras da soberania política para figuras de firmas financeirizadas. Esta conversão, por seu turno, produz duas reorientações significativas: por um lado, ela reorienta a relação do sujeito consigo mesmo e sua liberdade. Ao invés de se tornar um ser de poder e interesse, o Eu se torna capital para ser investido e melhorado conforme normas e critérios específicos e conforme insumos disponíveis. Por outro lado, esta conversão reorienta a relação do Estado com o cidadão. Os cidadãos não são mais os elementos constituintes mais importantes da soberania, membros do público, ou mesmo portadores de direitos. ${ }^{23}$ Em vez disso, enquanto capital humano, eles podem contribuir ou ser um peso para o crescimento econômico; podem ser objetos de investimento ou de desinvestimento, a depender de seu potencial para a melhoria do PIB.

É forçoso exagerar o significado destas duas reorientações - a do sujeito consigo mesmo e a do Estado para com o cidadão. Decerto, elas envolvem a dramática redução dos valores públicos, bens públicos, e participação popular na vida política. Igualmente óbvio, a governança de acordo com as métricas do mercado substitui critérios políticos liberais clássicos (justiça, proteção ao cidadão, equilíbrio de diversos interesses) pelas preocupações com o crescimento econômico, posicionamento concorrencial e avaliação de crédito. Todavia, conforme já sugerido, essas reorientações também envolvem um desaparecimento existencial da liberdade do mundo, justamente o tipo de liberdade individual e colaborativa associada ao homo politicus para o governo de si e o governo de outros. Ademais, o sujeito que é capital humano para si mesmo e para o Estado está sob um risco incessante de redundância e abandono (CLARKE, 2008, pp. 135-47). Enquanto capital humano, o sujeito, a um só tempo encarregado e responsável por si mesmo, é todavia um elemento dispensável para o todo. Essa não é senão outra forma pela qual o contrato social se vira do avesso.

Foucault estava ciente dessa possibilidade; ele descreveu o homo oeconomicus como "alguém [...] eminentemente governável, o correlato de uma governamentalidade [...] determinada de acordo com o princípio da economia." (FOUCAULT, 2004, pp. 270-71). Porém, ele não imaginou o extremo no qual esta governabilidade poderia se colocar sob o regime neoliberal, um extremo que se expressa pela fórmula da governança máxima por meio da máxima liberdade individual. No lugar da promessa liberal de garantir sujeitos dotados de soberania e autonomia políticas, o sujeito neoliberal não recebe nenhuma garantia de vida (muito pelo contrário, nos mercados, alguns devem morrer para que outros vivam), e está tão amarrado aos fins econômicos a ponto de poder ser sacrificado por eles.

Weber descreveu o capitalismo como originalmente um produto da combinação entre uma ética ascética, separações múltiplas (inter alia, entre proprietários e produtores, produção e troca) e uma racionalidade instrumental manejada para a produção eficiente da riqueza. A ironia, de fato a tragédia, do capitalismo para Weber é que este projeto original da técnica humana, quiçá de liberdade, culmina em um maquinário de dominação humana sem precedentes, que aprisiona o "Homem" em uma jaula de aço. Tal qual a burocracia, 
o capitalismo se inicia como um instrumento, mas se metamorfoseia em um sistema com fins próprios, restringindo todos os atores para servir àqueles fins.

O relato de Weber se mostra insuficiente no presente: a racionalidade neoliberal constrói muito mais do que uma jaula dentro da qual criaturas melancólicas espiam uma liberdade inatingível. Outrossim, a descrição de Marx para o capitalismo - vampiresco, explorador, alienante, inegualitário, enganador, movido pelo lucro, obsessivamente expansionista, fetichista, e profanador de todo valor, relação e esforço preciosos - é inadequada para [apreender] o que a racionalidade neoliberal forjou. Ainda que permaneça imbatível em sua representação do poder, imperativos, brutalidade e criação de capacidades globais do capitalismo, a análise de Marx também pressupunha sujeitos que ansiavam pela emancipação e que tinham em mãos um idioma político de justiça - princípios não cumpridos de democracia - por meio do qual demandá-la. Esses sujeitos e princípios não podem mais ser pressupostos.

Posto de forma ligeiramente diferente, Weber e Marx supõem um exterior político e uma subjetividade interior que estão em desarmonia com o capitalismo - a vida política contendo ao menos a promessa de liberdade, igualdade e soberania popular, estando a figura de personalidade subjetiva atrelada a ideais de merecimento, dignidade, autodirecionamento, até mesmo de vivacidade [soulfulness]. É justamente tal exterior e interior que a configuração, levada a cabo pela razão neoliberal, de Estados, cidadãos e almas na imagem do homo oeconomicus e a eliminação do homo politicus ameaçam extinguir.

\section{NOTAS}

1. A realização deste trabalho contou com auxílio da Fapesp (processo 2015/22251-0).

2. Ver também as respostas de Richard Sennett, Matt Welch, Deborah Sachs et al. no mesmo volume.

3. Alain Caille, "Anti-Utilitarianism, Economics and the Gift Paradigm" in Revue du MAUSS (Mouvement anti-utilitariste dans les sciences sociales), www.revuedumauss.com.fr/media/ACstake.pdf

4. Ver também Caille, "Anti-Utilitarianism, Economics and the Gift Paradigm".

5. Ver o periódico Cultural Economy, em que ocorre uma boa parte dessa teorização.

6. Ver também MITCHELL (2011) para outra variação de seu argumento.

7. Ver também p. 370 para uma definição do termo e CALLON (1998), no qual o autor o usa pela primeira vez.

8. Sobre responsabilização, ver O’MALLEY (2009, pp. 277-79). Ver também CLARKE (2008) e SHAMIR (2008).

9. Desse modo, o esforço persistente por investigar por que os eleitores da classe média e trabalhadora possam com frequência ser mobilizados "contra seus interesses" opera dentro de um paradigma anacrônico do liberalismo; tais eleitores têm se comportado como bons sujeitos neoliberais. Ver FRANK (2004).

10. Foucault diz que o homo juridicus difere do homo oeconomicus na medida em que este não tem nenhum soberano e não possa se sujeitar à soberania. Por conseguinte, a coexistência da governança soberana e econômica, do homo oeconomicus e homo juridicus, constitui uma problemática fundamental do liberalismo na visão de Foucault (Ibid, pp. 292-93).

11. Utlizamos, aqui, a tradução portuguesa de Antônio C. Amaral e Carlos de Carvalho Gomes (ARISTÓTELES, 1998, p. 81). 
12. No capítulo dois da Riqueza das nações, Smith escreve: "Não é nossa tarefa investigar aqui se essa propensão é simplesmente um dos princípios originais da natureza humana, sobre o qual nada mais restaria a dizer, ou se - como parece mais provável - é uma consequência necessária das faculdades de raciocinar e falar". (Repare como isto modifica a mudança aristotélica ao situar as supostamente distintas qualidades humanas da razão e do discurso na base de nossa natureza econômica, e não política.)

13. Nessa passagem da Teoria dos sentimentos morais, a representação de Smith daquilo que nos importa, em verdade, projeta um quadro bem amplo: "A administração do grande sistema do universo, [...] o cuidado da felicidade universal de todos os seres racionais, é negócio de Deus, e não do homem. Ao homem está reservado um departamento bem mais humilde, mas mais adequado à fraqueza de seus poderes e à estreiteza de sua compreensão: o cuidado da sua própria felicidade, ou da felicidade de sua família, amigos, país [...] Mas, embora assim dotados de um forte desejo por ver realizados esses fins, não foi confiado às lerdas e inseguras determinações de nossas razões descobrir os meios necessários para tanto. Para a quase totalidade desses casos, a natureza nos orientou com instintos primários e imediatos. Fome, sede, a paixão que une os dois sexos, o amor ao prazer, o temor à dor, incitam-nos a aplicar esses meios por si mesmos, independentemente de qualquer consideração sobre sua tendência àqueles fins benéficos, a qual o grande Diretor da natureza intentou construir" (SMITH, 1976b, p. 378). Considerações úteis sobre a descrição de Smith da natureza humana estão disponíveis em FLEISCHACKER (2004) e HOLLER (2006).

14. Foucault diz que o interesse é para Locke o que nos conduz para o contrato social. Entretanto, esta leitura oblitera a importância das leis de natureza no Segundo Tratado, nosso desejo de vê-las em vigência e nossa frustração ao tentar implementá-las por conta própria. As leis de natureza lockianas são princípios de justiça natural, e não simplesmente princípios de autointeresse (LOCKE, 1993, cap. 2, seções 6-13, pp. 270-74). “O estado de natureza tem uma lei de natureza para governá-lo, que obriga cada um deles [...] visto serem todos iguais e independentes, ninguém deve prejudicar outrem com relação a sua vida, saúde, liberdade ou posses [...] Todo mundo, como ele, é obrigado a se preservar $[. .$.$] devendo ele, o tanto quanto possa, preservar o resto da humanidade" (LOCKE, 1993, p. 271).$

15. "Qual seria então o limite legítimo [rightful] para a soberania do indivíduo sobre si mesmo? Onde começa a autoridade da sociedade?” (MILL, 1989, p. 75).

16. Aqui vai um esboço histórico resumido em um parágrafo: no despertar daquilo que chamamos de "o ocidente", o cidadão era um ser notoriamente político que participava no governo do comum, âmbito por meio do qual ele também se realizava, se aperfeiçoava e se libertava. Durante os longos séculos do feudalismo, essa noção vigorosa de cidadania esmoreceu à medida que a autoridade da Igreja e as monarquias se consagraram. Dessa noite escura, nasceram as revoluções da modernidade. Coincidindo com (e, em parte, fomentando) estas revoluções políticas, houve o surgimento de um modo de produção que afetava profundamente a vida política - modelando suas instituições, dirigindo seus conteúdos, condicionando suas linguagens -, mas que, ainda assim, não se amalgamava com ela, tampouco comandava inteiramente seus termos ou organizava seus princípios. Nesse momento, emergiu a figura do cidadão que, de um lado, formalmente tomava parte na soberania política, e de outro, estava inexoravelmente preocupado com seus próprios interesses e bem-estar, encontrando sua liberdade na busca de seus próprios fins. Inspirado por esse desejo e armado com seus direitos, tal figura cedeu a seus representantes sua preocupação com o domínio político compartilhado e correu atrás de suas próprias satisfações. Eis o sujeito cindido entre o "cidadão" e o "burguês" que persistiu, por dois séculos, na teoria democrático-liberal em que Marx baseia sua crítica do Estado liberal e que a forma neoliberal do homo oeconomicus finalmente deixará para trás.

\section{Ver COOPER (2017).}

18. Platão, em A República, pode ser considerado uma exceção interessante, salvo o fato de Platão despachar o homo politicus conforme estabelece a regra da república pela filosofia.

19. Ver, por exemplo, esse argumento de Becker: "A responsabilidade das mulheres casadas para com o cuidado infantil e outras tarefas do lar tem grandes implicações para os ganhos e diferenças ocupacionais entre homens e mulheres, mesmo para além do efeito sobre a participação da força de trabalho das mulheres casadas. Sugiro que essa é uma 
razão importante pela qual os ganhos das mulheres casadas são consideravelmente inferiores aos dos homens casados e pela qual uma segregação ocupacional substantiva persiste” (BECKER, 1991, p. 78).

20. Alguns têm argumentado que a estratificação de gênero é reduzida pelo neoliberalismo na medida em que ele envolve uma mudança de uma economia baseada na propriedade privada para uma economia baseada no capital humano. Elizabeth Mayes (2005), por exemplo, crê que a importância decrescente da propriedade privada é positiva para as mulheres por razões engelianas: se a subordinação das mulheres tem, ao longo da história, se ligado ao seu status de propriedade privada, as mulheres estariam, agora, livres para serem indivíduos ao invés de propriedades.

21. Eu moro, em 2014, em uma cidade progressista. As mulheres constituem noventa por cento dos que promovem atividades de apoio - direção, organização, provisão - para o time de esportes e conjunto de música do colégio do meu filho. Quase todas as mulheres que fornecem esse tipo de apoio têm nível educacional universitário e têm suas profissões.

22. Abstratamente livre e autárquico, o capital humano se distingue de outros tipos em virtude de sua subordinação ao seu empregador, sua indissolubilidade, e sua valoração por si mesmo e por outrem.

23. Uma definição sub verbo "Capital Humano" do Investopedia.com: "Uma medida do valor econômico de um conjunto de habilidades de um empregado. Esta medida se baseia na produção básica do insumo da medida de trabalho, no qual todo o trabalho se concebe como igual. O conceito de capital humano reconhece que nem todo trabalho é igual, e que a qualidade dos empregados pode ser melhorada por meio de investimentos. A educação, experiência e habilidades de um empregado têm um valor econômico para os empregadores e para a economia como um todo" (cf. http://www.investopedia.com/terms/h/humancapital.asp).

\section{REFERÊNCIAS}

ARISTÓTELES. 1946. Politics. Trad. de E. Barker. Oxford: Clarendon Press.

. 1998. Política. Edição bilíngue. Trad. de Antônio C. Amaral e Carlos de Carvalho Gomes. Loisboa: Vega.

BAIER, A. 1997. What Do Women Want with a Moral Theory? In: CRISP, R.; SLOTE, M. (Org.) Virtue Ethics. Oxford: Oxford University Press.

BECKER, G. S. 1991. A Treatise on the Family. Cambridge, MA: Harvard University Press.

BENTHAM, J. 1969. An Introduction to the Principles of Morals and Legislation. In: A Bentham Reader. Nova York: Pegasus.

BOWLES, S.; GINTIS, H. 1992. The Revenge of Homo Oeconomicus: Exchange and the Revival of Political Economy. Artigo não publicado.

BROWN, W. 1988. Manhood and Politics: A Feminist Reading in Political Theory. Totowa, NJ: Rowman and Littlefield.

CALISKAN, K.; CALLON, M. 2009. Economization, Part 1: Shifting Attention from the Economy Towards Processes of Economization. Economy and Society, vol. 38, n 3, pp. 369-98.

CALLON, M. 1998. The Embeddedness of Economic Markets in Economics. In: . (Org.) The Laws of the Markets. Oxford: Blackwell. 
CLARKE,J. 2008. Living With/in and Without Neo-Liberalism. Focaal-European Journal of Anthropology, 51, pp. 135-47.

COOPER, M. 2017. Family Values: Between Neoliberalism and the New Social Conservatism. Nova Iorque: Zone Books.

DILLON, S. 2005. Harvard Chief Defends His Talk on Women. New York Times, 18 de Janeiro.

DIXON, W.; WILSON, D. 2012. A History of Homo Economicus: The Nature of the Moral in Economic Theory. Nova Iorque: Routledge.

ELSHTAIN, J. 1993. Public Man / Private Woman: Women in Social and Political Thought. Princeton: Princeton University Press.

ENGLAND, P. 2005. Separative and Soluble Selves: Dichotomous Thinking in Economics. In: FINEMAN, M. A.; DOUGHERTY, T. (Org.) Feminism Confronts Homo Oeconomicus: Gender, Law, and Society. Ithaca: Cornell University Press.

FERGUSON, K. 1993. The Man Question: Visions of Subjectivity in Feminist Theory. Berkeley: University of California Press.

FLEISCHACKER, S. 2004. On Adam Smith's Wealth of Nations: A Philosophical Companion. Princeton: Princeton University Press.

FOUCAULT, M. 2004. The Birth of Biopolitics: Lectures at the Collège de France, 1978-79. Ed. de Michel Senellart, trad. de Graham Burchell. Nova Iorque: Picador.

FRANK, T. 2004. What's the Matter With Kansas? How Conservatives Won the Heart of America. Nova Iorque: Holt.

FREUD, S; 2010. Civilization and Its Discontents. Trad. de James Strachey. Nova York: Norton.

FRIEDMAN, M. 1962. Capitalism and Freedom. Chicago: University of Chicago Press.

HEGEL, G. W. F. 1952. The Philosophy of Right. Trad. de T. M. Knox. Oxford: Oxford University Press.

HIRSCHMAN, A. O. 1977. The Passions and the Interests: Political Arguments for Capitalism Before Its Triumph. Princeton: Princeton University Press.

1984. Against Parsimony: Three Easy Ways of Complicating Some Categories of Economic Discourse. Bulletin of the American Academy of Arts and Sciences, vol. 37, no 8, pp. 11-28.

HOLLER, J. 2006. Adam Smith's Model of Man and Some of its Consequences. Homo Oeconomicus, vol. 23, no. 3, pp. 467-88.

KEYNES, J. M. 1936. The General Theory of Employment, Interest and Money. Kissimmee: Signalman.

KLAMER, A. 2001. Late Modernism and the Loss of Character in Economics. In: CULLENBERG, S.; ARMARIGLIO,J.; RUCCIO, D. F. (Org.).Postmodernism, Economics, and Knowledge. Nova Iorque: Routledge. 
LAVAL, C. 2007. L’homme économique: essai sur les racines du néolibéralisme. Paris: Gallimard.

LOCKE,J. 1993. Two Treatises of Government. In: WOOTTON, D. (ed.) Political Writings. Nova York: Penguin.

MACPHERSON, C. B. 1962. The Political Theory of Possessive Individualism: Hobbes to Locke. Oxford: Oxford University Press.

MALTHUS, T. 1993. An Essay on the Principle of Population. Oxford: Oxford University Press.

MARX, K. 1978a. On the Jewish Question. In: The Marx-Engels Reader. Nova Iorque: Norton.

Norton . 1978b. The Eighteenth Brumaire of Louis Bonaparte. In: The Marx-Engels Reader. Nova Iorque: . 1978c. The German Ideology. In: The Marx-Engels Reader. Nova Iorque: Norton.

MAUSS, M. 1990. The Gift: The Form and Reason for Exchange in Archaic Societies. Trad. de W. D. Halls. Nova Iorque: Routledge.

MAYES, E. 2005. Private Property, the Private Subject, and Women: Can Women Truly Be Owners of Capital? In: FINEMAN, A.; DOUGHERTY T. (Org.) Feminism Confronts Homo Oeconomicus. Ithaca: Cornell University Press.

MCCLOSKEY, D. 2005. The Demoralization of Economics: Can We Recover from Bentham and Return to Smith? In: FINEMAN, M. A.; DOUGHERTY, T. (Org.) Feminism Confronts Homo Oeconomicus: Gender, Law, and Society. Ithaca: Cornell University Press.

MILL, J. S. 1967. On the Definition of Political Economy and on the Method of Investigation Proper to It. In: The Collected Works of John Stuart Mill, vol. 4. Ed. J. M. Robson. Toronto: University of Toronto Press.

. 1989. On Liberty and Other Writings. Ed. de S. Collini. Cambridge: Cambridge University Press

MITCHELL, T. 2002. Rule of Experts: Egypt, Techno-Politics, Modernity. Berkeley: University of California Press.

2011. Carbon Democracy. Londres: Verso.

NELSON, J. 1993. Beyond Economic Man: Feminist Theory and Economics. Chicago: University of Chicago Press.

. 1995. Feminism and Economics. Journal of Economic Perspectives, vol. 9, no 2, pp. 131-48.

O’MALLEY, P. 2009. In: WAKEFIELD, A.; FLEMING, J. (Org.) The SAGE Dictionary of Policing. London: SAGE Publications Ltd.

POLANYI, Karl. 2001. The Great Transformation. Boston: Beacon.

RICARDO, D. 1973. The Works and Correspondence of David Ricardo. Londres: Cambridge University Press. 
ROSE, C. M. 1990. Property as Storytelling: Perspectives from Game Theory, Narrative Theory, Feminist Theory. Yale Journal of Law and the Humanities, vol. 2, no 1, pp. 37-57.

ROUSSEAU, J.-J. 1968. The Social Contract. Trad. de M. Cranston. Nova York: Penguin.

SAHLINS, M. 1972. Stone-Age Economics. Chicago: Aldine Publishing.

. 2013. On the Culture of Material Value and the Cosmography of Riches. HAU: Journal of Ethnographic Theory, vol. 3, no 2, pp. 161-95.

SANDEL, M. 2012a. How Markets Crowd Out Morals. Boston Review 37.3.

.2012b. What Money Can't Buy: The Moral Limits of Markets. Nova Iorque: Farrar, Strauss and Giroux.

SCOTT, J. 1997. Only Paradoxes to Offer: French Feminists and the Rights of Man. Cambridge, MA: Harvard University Press.

SHAMIR, R. 2008. The Age of Responsibilization: On Market-Embedded Morality. Economy and Society, vol. 37, no 1, pp. 1-19.

SMITH, A. 1976a. The Wealth of Nations. Chicago: University of Chicago Press. . 1976b. Theory of Moral Sentiments. Indianapolis: Liberty Classics.

TABAS, S. B. 2009. After Nature: Homo Oeconomicus and the Aesopic Fable. [Tese (Doutorado)] New York University, Department of Comparative Literature.

THUILLIER, P. 1995. La grande implosion. Paris: Fayard.

TRONTO, J. 1993. Moral Boundaries: A Political Argument for an Ethic of Care. Nova Iorque: Routledge.

WEBER, M. 1948. Politics as a Vocation. In: Essays in Sociology. Ed. e trad. por H. H. Gerth e C. Wright Mills. Nova Iorque: Routledge.

ZERILLI, L. 1994. Signifying Woman: Culture and Chaos in Rousseau, Burke, and Mill. Ithaca: Cornell University Press. 